\title{
Relationship between waxy (high amylopectin) and high protein digestibility traits in sorghum and malting quality
}

\author{
Abadi G. Mezgebe ${ }^{1,2}$, Kebede Abegaz ${ }^{2}$, John R. N. Taylor ${ }^{1 *}$ \\ ${ }^{1}$ Department of Food Scienceand Institute for Food, Nutrition and Well-being, University of \\ Pretoria, Private Bag X20, Hatfield 0028, Pretoria, South Africa \\ ${ }^{2}$ School of Nutrition, Food Science and Technology, College of Agriculture, Hawassa \\ University, P.O.Box 05, Hawassa, Ethiopia
}

*Corresponding Author: John R.N. Taylor

Phone: +27 124204296

Fax: +27 124202839

E-mail: john.taylor@up.ac.za

Keywords: amylopectin; malting; protein digestibility; sorghum

\begin{abstract}
Abbreviationsused:FAN - free amino nitrogen; HD - high protein digestibility trait;HWE hot water extract;IVPD- in vitro protein digestibility; SEM - scanning electron microscopy; TEM- Transmission electron microscopy; WND- waxy-normal protein digestibility; hWNDheterowaxy-normal protein digestibility; WHD- waxy-HD; NWHD- non-waxy-high protein digestibility; NWND- non-waxy-normal digestibility; HSD- honest significant differencetest; PCA- principal component analysis
\end{abstract}

Running head: Waxy and high protein digestibility sorghum malting quality 


\begin{abstract}
This study determined the relationship between waxy (high amylopectin) and high protein digestibility (HD) traits in sorghum and malting quality with the aim of replacing barley malt in arid, tropical regions. Eight sorghum lines with differing endosperm traits: waxy, heterowaxy, waxy-HD, non-waxy-HD and non-waxy-normal digestibility traits were malted at a laboratory scale and their malt quality and modification during malting were studied. Malt from waxy and heterowaxy sorghum lines generally had improved endosperm modification and starch granule degradation. Only non-waxy-HD and one waxy line malts exhibited clear evidence of endosperm protein degradation. Malt $\alpha$-amylase activity of the sorghum lines varied more than $\beta$-amylase activity but neither were evidently affected by the traits. Malt from waxy lines had improved HWE and FAN. Principal component analysis showed that waxy lines were associated with high HWE, FAN, starch and protein loss. The improved malt quality was probably due to the better starch granule swelling property of amylopectin which could have facilitated hydrolysis by amylases and proteases. This study shows that although $\beta$-amylase activity is not affected by the waxy trait, white tan-plant waxy sorghum produces high quality malt than regular sorghum and has potential as a better partial barley malt replacement for brewing.
\end{abstract}




\section{Introduction}

Alternative cereals to barley for malting are essential because of climate change, non-viable cultivation of barley in tropical and sub-tropical regions, demand for gluten-free products, increased food product variety and to improve global food security (Taylor et al., 2013). Sorghum malt is used as a functional component of many traditional African beers and porridges, and in modern lagers, stouts, and non-alcoholic malt beverages (Taylor and Emmambux, 2008). However, there are several factors that limit the use and functionality of sorghum malts for modern beers and non-alcoholic beverages, among these are low $\beta$ amylase activity, incomplete degradation of its starch into fermentable sugars and limited proteolysis (Taylor et al., 2013).

Sorghum malt starch gelatinization temperature is high, $64-68^{\circ} \mathrm{C}$, some $10^{\circ} \mathrm{C}$ higher than that of barley malt starch and this majorly adversely influences the hydrolysis of the starch by the malt $\alpha$-amylase (Taylor, 1992). This problem is exacerbated by disulphide bond mediated cross-linking of the prolamins and other endosperm proteins which may also limit starch granule expansion (Chandrashekar et al., 1988) and hence subsequent hydrolysis of the starch to fermentable sugars (Ezeogu et al., 2005). Prolamin cross-linking during wet heating also restricts enzymatic hydrolysis of the endosperm proteins into free amino nitrogen (FAN) (Duoduet al., 2003).

Waxy (high amylopectin) type barley has been found to show improved amylolysis (Vasanthan and Hoover, 2009). Furthermore, there has been considerable interest in using malted and unmalted waxy sorghum in lager beer brewing (Ortega Villicaña and SernaSaldivar, 2004). Unmalted waxy sorghum as adjunct in brewing trials showed more rapid starch hydrolysis (Figueroa et al., 1995) and gave higher extract, filtered more rapidly and produced wort with the same level of fermentable carbohydrates as normal sorghum (OsorioMorales et al., 2000).

Sorghum lines with improved protein digestibility (HD) due to endosperm protein expression modification either by conventional breeding or genetic engineering also have improved brewing quality. Mugode et al. (2011) found that malted HD lines were substantially higher in FAN than normal sorghums. However, the HD lines were not higher in FAN when mashed. Furthermore it has been found that transgenic unmalted sorghum lines with the HD trait gave increased hot water extract (HWE) and wort FAN (Kruger et al., 2012). Recently, 
sorghum lines that express both the waxy and HD-traits have been developed by Texas A\&M University through conventional breeding and some of these lines have been found to be promising for grain bioethanol use, having more easily pasted starch granules, yielding higher FAN, giving faster fermentation and producing more lysine-rich distillers dried gain and solubles (DDGS) (Wu et al., 2010).

Despite the potential advantages of waxy and HD sorghums in brewing, there has been very little research into their malting quality and the malting properties and malt quality of the combined waxy and HD sorghum types has not been investigated. Hence, this study evaluated the malting performance and quality of sorghum lines with waxy, heterowaxy, HD combined with waxy, normal endosperm and normal protein digestibility traits in respect of endosperm modification during malting, and critical malt quality parameters of $\alpha$ - and $\beta$ amylase activity, HWE, and FAN.

\section{Materials and Methods}

\subsection{Materials}

Eight sorghum lines were investigated. All were tannin-free white, tan-plant types and derived from crosses between lines RTx2907 and P850029 by Texas A\&M Agrilife Research, Texas, USA. They were cultivated at the Ukulima research farm, Limpopo Province, South Africa in a controlled field trial in the 2014-2015 season. The grains of the lines were all visually indistinguishable. RTx2907 is a waxy and normal protein digestibility sorghum released from the Texas Agrilife sorghum breeding program (Miller et al., 1996), while P850029 is a high protein digestibility line that was developed by Purdue University from the high lysine line P721Q (Weaver et al., 1998). The lines comprised three waxynormal protein digestibility (WND), one heterowaxy-normal protein digestibility (hWND), two waxy-HD (WHD), one non-waxy-high digestibility (NWHD) and one non-waxy-normal digestibility (NWND) type.

Commercial barley malt (variety Cocktail) kindly provided by the Cereal and Malt Extract company and commercial sorghum malt (white Type-II tannin sorghum, Feterita-type variety) kindly supply by SABMiller Africa were included as references. The white Type-II tannin sorghum had a tannin content of approx. $0.5 \mathrm{~g}$ catechin equiv./100 g (Adetunji et al., 2013). Additionally, the general desired range of each critical malt quality parameter of barley malt for brewing is also included (Table 2). 
Unmalted sorghum grain and the malts were milled for analyses using a hammer mill (Falling Number AB, Huddinge, Sweden) fitted with a $0.5 \mathrm{~mm}$ opening screen.

\subsection{Malting}

All the sorghum lines had a Germinative Energy of $\geq 90 \%$. They were malted at the laboratory scale under standard conditions following the method of Dewar et al. (1997). Cleaned grains $(100 \mathrm{~g})$ were steeped at $25^{\circ} \mathrm{C}$ for $24 \mathrm{~h}$ with the steeping vessel being drained every 3 hours and the steeped grain given a $1 \mathrm{~h}$ air-rest. The steeped sorghum was germinated for 3 days at $25^{\circ} \mathrm{C}$. A three-day germination period was chosen because scanning electron microscopy revealed significant differences between the levels of endosperm modification at the endosperm distal end between the sorghum lines (section 3.2.1) and also to minimise the high malting losses that occur with sorghum. Germination was conducted at medium moisture level (Morrall et al., 1986), meaning that the moisture content of the green malt was kept constant throughout germination period. After germination, the malt was dried at $50^{\circ} \mathrm{C}$ for $24 \mathrm{~h}$ in a forced-draft oven to a shelf-stable moisture content of 5-7\%. The roots and shoots were separated from the kernels by rubbing the dried malt against a sieve $(1.4 \mathrm{~mm}$ opening screen).

\subsection{Analyses}

\subsubsection{Sorghum grain endosperm texture}

Endosperm texture, defined as the proportion of corneous endosperm relative to floury endosperm in the grain, was determined according to ICC Standard 176 (ICC, 2011) by viewing 20 longitudinally sectioned kernels (with germ) using a stereomicroscope.

\subsubsection{Starch content}

The starch content of the unmalted and malted sorghum lines was determined using the Megazyme Total Starch assay procedure (Amyloglucosidase/ $\alpha$-amylase method) (Megazyme Ireland International, Bray, Ireland). The assay employs thermostable $\alpha$-amylase to hydrolyze starch into soluble branched and unbranched maltodextrins and amyloglucosidase to quantitatively hydrolyze the maltodextrins to D-glucose. Then oxidised D-Glucose is quantitatively measured colorimetrically. 


\subsubsection{Protein content}

The protein content $(\mathrm{N} \times$ 6.25) of the unmalted and malted sorghum lines was determined by a Dumas combustion assay according to AACC method 46-30 (AACC International, 2000).

\subsubsection{Starch amylopectin content}

The Megazyme assay kit for Amylose/Amylopectin (Megazyme Ireland International, Bray, Ireland) was used to determine starch amylopectin content. Amylopectin is specifically precipitated by the addition of the lectin concanavalin A (Con-A) and removed by centrifugation. The amylose in the supernatant is enzymatically hydrolysed to D-glucose, and measured colorimetrically. The starch amylopectin content is then calculated by subtracting the amylose content from 100.

\subsubsection{In-vitro protein digestibility (IVPD)}

IVPD of wet cooked sorghum flours was determined by the pepsin digestion assay described by Da Silva et al. (2011b) based on that of Hamaker et al. (1986). Nitrogen was then quantified by the Dumas combustion assay.

\subsubsection{Germinative energy}

Germinative energy of the sorghum lines was measured at $72 \mathrm{~h}$ according to ICC Standard 174 (ICC, 2011).

\subsubsection{Transmission Electron Microscopy (TEM)}

Protein body morphology of the unmalted and malted sorghum lines was assessed using TEM as described (Da Silva et al., 2011b) with some modifications in fixing and dehydration. Sections of the periphery of the mid-endosperm (1-2 mm thick) were fixed in glutaraldehyde in pH 7.4 phosphate buffer $(18 \mathrm{~h})$ and stained with osmium tetraoxide. Samples were dehydrated sequentially in ethanol. Samples were infiltrated with Quetol resin and polymerised at $60^{\circ} \mathrm{C}$. Ultra-thin sections were stained with uranyl acetate, and Reynold's lead citrate, and viewed using a field emission transmission electron microscope (JEOL JEM2100F, Japan).

\subsubsection{Scanning Electron Microscopy (SEM)}

Endosperm modification during malting was evaluated using SEM by immersing the malt in liquid nitrogen at $-196^{\circ} \mathrm{C}$ and cutting the sample longitudinally through the germ using a 
sharp blade. Fixed kernels were sputter coated with carbon ( 5 times on the top, 2 times on each side) and then viewed using a Zeiss Evo LS15 field emission scanning electron microscope (Carl Zeiss, Oberkochen, Germany) operated at an acceleration voltage of $8 \mathrm{kV}$.

\subsubsection{Alpha-amylase activity}

Malt $\alpha$-amylase activity was determined using the Megazyme Ceralpha kit method (Megazyme International, Bray, Ireland). The assay employs non-reducing-end blocked $p$ nitrophenyl maltoheptaoside (BPNPG7) as substrate. On hydrolysis of the BPNPG7 by endoacting $\alpha$-amylase, the excess quantities of $\alpha$-glucosidase present in the mixture give instantaneous and quantitative hydrolysis of the $p$-nitrophenyl maltosaccharide fragment to glucose, which is then measured colorimetrically.

\subsubsection{Beta-amylase activity}

Malt $\beta$-amylase activity was determined using the Megazyme Betamyl-3 kit method (Megazyme International, Bray, Ireland). The assay employs high purity $p$-nitrophenyl- $\beta$-Dmaltotrioside (PNP $\beta-\mathrm{G} 3$ ) as substrate. On hydrolysis of the PNP $\beta-\mathrm{G} 3$ to maltose and $p$ nitrophenyl- $\beta$-Dglucose by $\beta$-amylase, the $p$-nitrophenyl- $\beta$-D-glucose is immediately cleaved to D-glucose and free $p$-nitrophenol by the $\beta$-glucosidase present in the substrate mixture, and the glucose is measured colorimetrically.

\subsubsection{Hot Water Extract (HWE)}

Malt HWE was determined according to theEuropean Brewery Convention (EBC, 1998) Method 4.5.1 Extract of Malt: Congress Mash (AM), modified toa10 g malt sample size by reducing volumes in proportion. HWE was quantified by specific gravity in ${ }^{\circ} \mathrm{P}$ using pycnometry. The rising temperature EBC Congress barley malt mashing procedure was used in this study because when sorghum malt is used in large-scale lager-type brewing, it is invariably as a partial barley malt replacement and mashed together with barley malt using a barley type mashing process (Taylor and Emmambux, 2008).

\subsubsection{Free amino nitrogen (FAN)}

FAN contents of the malts was determined using the European Brewery Convention ninhydrin assay Method 4.10 (EBC, 1998) as modified by Morall et al. (1986). Glycine was used as a standard and the results were expressed as mg FAN/100 g dry malt. 


\subsubsection{Malting loss}

Malting loss was assessed by weighing batches of 100 sound kernels of the dried malt (after root and shoot removal) and comparing it with the weight of 100 sound unmalted grains.

\subsubsection{Starch and protein losses}

The starch and protein losses after malting were assessed by comparing the starch and protein contents of the dried malts (after root and shoot removal) with those of the unmalted grains.

\subsection{Statistical analyses}

Malting was performed at least twice and closely agreeing replicates were obtained. All chemical analyses on both replicates were repeated at least twice. The data for starch content, protein content, starch amylopectin content, in-vitro protein digestibility and the malt quality attributes were analysed using one-way ANOVA. The means were separated using Tukey's HSD test at $\mathrm{p}<0.05$. Principal Component Analysis (PCA) for all numerical results was performed using XLSTAT version 2016.03.30882 (Addinsoft, New York).

\section{Results and Discussion}

\subsection{Characterisation of the sorghum lines}

The eight sorghum lines exhibited a wide range of endosperm types, starch amylopectin contents, protein body morphology and cooked flour IVPD. The endosperm of five of the lines (WND1, WND2, WND3, WHD1 and WHD2) had a pale waxed floor-like appearance (Fig. 1), typical of waxy sorghum (Rooney and Miller, 1982). Furthermore, their starch amylopectin contents were high, ranging between 87.9 and $94.1 \%$ (Table 1). Three of these waxy lines (WND1, WND2 and WND3) had an intermediate to corneous endosperm (Fig. 1). In contrast, two of the lines (WHD1 and WHD2) had a predominantly floury endosperm. Of the other three lines, NWND and hWND had a predominantly corneous endosperm, while NWHD had a floury endosperm. All the three had lower starch amylopectin contents (79.9$85.4 \%$ ) (Table 1), indicating that they were non-waxy and heterowaxy sorghum types (Sang et al., 2008).

Concerning protein body morphology and protein digestibility, TEM revealed that waxy-HD lines (WHD1 and WHD2) had protein bodies which were not densely packed in the protein matrix, of irregular shape and small size (0.48-0.56 $\mu \mathrm{m}$ diam.)(Fig. 2 and Table 1), typical of 
HD sorghum lines (Da Silva et al., 2011b). These lines had generally higher cooked flour IVPD (57.1-62.5\%) than the other lines (Table 1), but the relative increase in protein digestibility was only moderate. Furthermore, these lines had floury endosperms (Fig. 1). This is agreement with previous work that has shown that the sorghum types with the HD trait exhibit a floury character (Elhassan et al., 2015). Line NWHD also had a relatively high cooked IVPD (65.9\%), but its protein bodies were normal in shape (Fig. 2). However, the kernels were indented (as opposed to being essentially spherical) and the endosperm was relatively small and almost completely floury, suggesting that other mutations had occurred. The smallish and floury nature of the endosperm may have been responsible for its relatively high protein digestibility.

As all eight sorghum lines were closely related, had similar starch (73.0-78.5\%) and protein (12.0-13.8\%) contents (Table 1) and had high Germinative energy ( $\geq 90 \%)$, they were considered to be appropriate for comparison the influence of the starch and protein digestibility traits on malting quality.

\subsection{Malt modification}

\subsubsection{Endosperm modification}

SEM of the malts of all lines after 3 days germination revealed that the floury endosperm near the endosperm-scutellum interface (proximal region), there was extensive degradation of the starch granules and the protein bodies were no longer visible (Fig. 3). The extent of the degradation of starch granules and endosperm protein seemed to reduce gradually towards the distal region. The waxy-normal protein digestibility (WND1, WND2, WND3) (Fig. 3M,P,V), heterowaxy-normal protein digestibility (hWND) (Fig. 3G) and the waxy-high protein digestibility (WHD2) (Fig. 3S) lines showed greater starch granule modification compared to the normal starch and protein digestibility line (NWND) (Fig. 3A), as evidenced by greater pitting of starch granules (indicated by SGd with two arrows). However, the floury endosperm non-waxy-HD line (NWHD) (Fig. 3B) did not show a higher degree of endosperm modification. Though the sorghum lines were not statistically significant different ( $>0.05$ ) in their malting loss (Table 2), the higher degree of endosperm modification of the waxy lines was consistent with the indication of relatively higher malting loss than the normal sorghum lines. The greater tendency of endosperm modification with the waxy sorghum lines either combined with high or normal protein digestibility indicates that the amylopectin-rich starch was more readily modified. 
SEM of the periphery of the mid-endosperm region revealed slight modification in all the lines (Fig. 3). The corneous endosperm cells of the waxy-normal digestibility lines (WND1, WND2, WND3) (Fig. 3N,Q,W) and the waxy-HD line (WHD2) (Fig. 3T) showed greater modification than the non-waxy, normal digestibility line (NWND) (Fig. 3B). The distal regions showed slightly greater modification in the waxy lines (WND2, WND3 and WHD2), which had highest starch amylopectin content (Table 1)(Fig. 3R,X,U).

\subsubsection{Protein body degradation}

TEM of the periphery of the mid endosperm region of the sorghum lines showed that the protein bodies and surrounded matrix were degraded to differing extents between the lines as evidenced by the relative disappearance of margins of the protein bodies (indicated by white arrow with M) and degree of erosion (white arrow) (Fig. 2). Lines NWHD, WND1, and WND2 showed the highest level of endosperm protein degradation. Malts of hWND and WND3 showed slight endosperm protein degradation, while lines of WHD1, WHD2 and NWND did not show any endosperm protein degradation. Hence, the study did not show any clear trend as to whether the HD trait in the lines improved the degradation of the endosperm protein, unlike the situation with starch granule degradation (Fig. 3).

\subsection{Malt quality}

\subsubsection{Alpha-amylase activity}

The malt $\alpha$-amylase activity of the sorghum lines varied considerably, ranging from 79.3 to 168.5 CU/g (Table 2). Lines WND2 and WND3 had similar ( $\mathrm{p} \geq 0.05) \alpha$-amylase activity to the commercial barley malt (131.2 CU/g) and line WHD2 had significantly higher activity $(\mathrm{p}<0.05)$. Dufour et al. (1992) also found that sorghum malts exhibited similar or even higher $\alpha$-amylase activities than typical lager barley malts. All the sorghum lines had lower $\alpha$-amylase activity than the desired values of barley malt for brewing (200-250 CU/g) and much higher ( 3 to 6 fold) than the $\alpha$-amylase activity of commercial sorghum malt. However, the commercial sorghum malt was white tannin-type II and the tannins present could have inhibited its amylase activity (Adetunji et al., 2013).

Concerning the relationship between the waxy and HD traits and $\alpha$-amylase activity, one of the waxy plus high protein digestibility line (WHD2) had significantly $(p<0.05)$ higher $\alpha-$ amylase activity than the normal line (NWND), whereas the other line with same traits 
(WHD1) had lower $\alpha$-amylase activity. A similar trend was observed for the heterowaxy and waxy sorghum malts, as WND1 and hWND had lower $\alpha$-amylase activity, while WND2 and WND3 had higher compared to normal line. Only HD line (NWHD) had similar ( $\geq \geq 0.05) \alpha-$ amylase activity to the NWND line. Thus, the malt $\alpha$-amylase activity was not evidently affected by the waxy and HD traits.

\subsubsection{Beta-amylase activity}

The malt $\beta$-amylase activity of the lines also varied considerably, ranging from 2.1 to 4.8 Betamyl-3® U/g (Table 2). However, all the sorghum malts had much lower $\beta$-amylase activity compared to the barley malt (12 BU/g db). Studies by Dufour et al. (1992) showed that malted sorghum $\beta$-amylase activity was much less than that of barley malt. When compared to the desired value of barley malt $\beta$-amylase activity for brewing (500 BU/g), all the sorghum lines had very much lower $\beta$-amylase activity. As with $\alpha$-amylase activity, the malts of all eight lines had much higher malt $\beta$-amylase activity than the commercial sorghum malt, probably as a result of it containing tannins.

Regarding the relationship between the waxy and HD traits and $\beta$-amylase activity, the waxyHD line (WHD1) and heterowaxy line (hWND) were significantly $(\mathrm{p}<0.05)$ lower in $\beta$ amylase activity compared to the normal line (NWND), whereas the other lines (NWHD, WND1, WND2, WND3, and WND2) all had similar ( $\mathrm{p} \geq 0.05) \beta$-amylase activity to NWND. Hence, the $\beta$-amylase activity of the sorghum malts also seemed to vary irrespective of the waxy and HD traits.

\subsubsection{Hot water extract (HWE)}

HWE content of the malted sorghum lines varied widely, between 44.2 and $64.2 \%$ (Table 2). With regard to the relationship between the waxy and HD traits and HWE, the sorghum line with both the waxy and high protein digestibility (WHD2) traits gave the highest extract, significantly higher HWE $(\mathrm{p}<0.05)$ than the non-waxy sorghum lines (NWND, NWHD) and comparable to the barley malt ( $\mathrm{p} \geq 0.05$ ). The waxy and normal digestibility (WND1, WND2 and WND3) traits also yielded higher HWE ( $\mathrm{p} \geq 0.05)$ than the non-waxy sorghum lines. The higher HWE of the waxy lines compared to the non-waxy lines is consistent with them exhibiting higher endosperm modification as evidenced by their greater starch granule degradation (Fig. 3). Line WHD1, however, gave a very low HWE (44.2\%), despite it having 
both the waxy and high protein digestibility traits. Its low extract can be attributed to its very low $\alpha$-amylase activity (Table 2). Moreover, all the sorghum lines had lower HWE compared to the generally required value for brewing $(>81 \%)$.

PCA revealed that the waxy lines (WND1, WND2, WND3 and WHD2) were aligned together with HWE, together with starch and malting losses (Fig. 4a). This is indicative of greater starch modification in the waxy lines resulting in more precocious germination and hence higher malting losses. In fact, with the exception of the WHD1 (the line with low $\alpha$ amylase activity) all the waxy lines were in the same PC1 quadrant (47.5\% of the variation) as HWE. PCA with the WHD1 line removed revealed this more clearly (Fig. 4b). Thus, it seems that the waxy (high amylopectin) trait is highly associated with high HWE in sorghum malt. This is probably a consequence of the better starch granule swelling property of amylopectin (Tester and Morrison, 1990), facilitating greater hydrolysis by amylases. As a result, waxy starch is more easily hydrolyzed by $\alpha$-amylase (Wu et al., 2010). The findings of this current study are in agreement with other research into unmalted cereals where waxy and heterowaxy sorghums (Osorio-Morales et al., 2000) and waxy barley (Vasanthan and Hoover, 2009) were found to have improved starch hydrolysis. The findings are also in agreement with the work of Wong et al. (2009) who showed that in two unmalted sorghum lines with a common pedigree, the waxy line, which also had a weak protein matrix, was more susceptible to hydrolysis by $\alpha$-amylase.

\subsubsection{Free Amino Nitrogen (FAN)}

The FAN content of the malted sorghum lines varied, ranging between71.5and $103.2 \mathrm{mg} / 100$ $\mathrm{g}$ (Table 2). Lines WND1 and NWHD had the highest FAN content (103.2 and $99.6 \mathrm{mg} / 100$ $\mathrm{g}$, respectively), significantly higher $(\mathrm{p}<0.05)$ than that of the commercial barley malt reference $(83.5 \mathrm{mg} / 100 \mathrm{~g})$. These lines also exhibited high endosperm protein matrix and protein body degradation (Fig. 2). The waxy (WND2 and WND3) and waxy-high protein digestibility (WHD2) lines produced similar FAN ( $\mathrm{p} \geq 0.05)$ to the barley malt. However, the sorghum lines were still lower in FAN compared to the desired value of barley malt FAN for brewing. PCA (Fig. 4) indicated that the waxy-normal protein digestibility lines (WND1 and WND2) were associated with high malt FAN, while WND3 and WHD2 with protein loss. Also, as with HWE, all the waxy lines, with exception of the low $\alpha$-amylase WHD1, were in the same PC1 quadrant as high FAN. This finding is consistent with the observation by Rooney and Pflugfelder (1986) that sorghums with waxy endosperm and a relatively weak 
protein matrix are more susceptible to hydrolysis by amylase and protease enzymes.

However, the HD trait was not associated with high malt FAN. In fact, malt FAN seemed to be more associated with unmalted grain protein content. It seemed that any effect of the moderate increase in protein digestibility in the HD lines was not significant in comparison to the effect of the waxy trait. The finding is consistent with the observation by Wong et al. (2009) that the waxy trait in sorghum could enable the endosperm proteins to be exposed to proteases.

\section{Conclusions}

Malts from waxy sorghums exhibit greater endosperm modification during germination and generally yield higher malt hot water extract despite the fact that $\beta$-amylase activity is not affected. The HD trait, however, does not clearly affect malt FAN, probably because its affects are obscured by those of the waxy trait. As the level of HWE from malted waxy sorghums was higher than that of the regular sorghums and more close to malted barley, white tan-plant waxy sorghum malt has considerable potential to replace part of the barley malt used in beer brewing in arid, tropical regions where barley cannot be economically cultivated.

\section{Acknowledgements}

This study is made possible by the support of the American People provided to the Feed the Future Innovation Lab for Collaborative Research on Sorghum and Millet (SMIL) through the United States Agency for International Development (USAID) under Cooperative Agreement No. AID-OAA-A-13-00047. The contents are the sole responsibility of the authors and do not necessarily reflect the views of USAID or the United States Government. Mr Alan N Hall and Ms Erna Van Wilpe of the University of Pretoria's Laboratory for Microscopy and Microanalysis are also acknowledgedfor assistance with the microscopy study.

\section{References}

AACC International, 2000.Crude Protein-combustion, Standard Method 46-30. In: Approved Methods of the AACC, tenth ed. The Association, St Paul, MN. 
Adetunji, A.I., Khoza, S., De Kock, H.L., Taylor, J.R.N., 2013. Influence of sorghum grain type on wortphysico-chemical and sensory quality in awhole-grain and commercial enzyme mashingprocess. J. Inst. Brew.119, 156-163.

Chandrashekar, A., Kirleis, A.W., 1988. Influence of protein on starch gelatinization in sorghum. Cereal Chem. 65, 457-462.

Da Silva, L.S., Jung, R., Zhao, Z., Glassman, K., Grootboom, A.W., Mehlo, L., O'Kennedy, M.M., Taylor, J., Taylor, J.R.N., 2011b. Effect of suppressing the synthesis of different kafirin sub-classes on grain endosperm texture, protein body structure and protein nutritional quality in improved sorghum lines. J. Cereal Sci. 54, 160-167.

Dewar, J., Taylor, J.R.N., Berjak, C., 1997. Effect of germination conditions, with optimized steeping, on sorghum malt quality - with particular reference to free amino nitrogen. J. Inst. Brew. 103, 171-175.

Dufour, J. P., Mélotte, L., Srebrnik, S., 1992. Sorghum malts for the production of lager beer. J. Am. Soc. Brew. Chem. 50, 110-119.

Duodu, K.G., Taylor, J.R.N., Belton, P.S., Hamaker, B.R., 2003. Factors affecting sorghum protein digestibility. J. Cereal Sci. 38, 117-131.

Elhassan, M.S.M, Emmambux, M.N., Hays, D.B., Peterson, G.C., Taylor, J.R.N., 2015. Novel biofortified sorghum lines with combined waxy (high amylopectin) starch and high protein digestibility traits: Effects on endosperm and flour properties. J. Cereal Sci. $65,132-139$.

European Brewery Convention (EBC), 1998. Extract of Malt: Congress Mash (AM) Method 4.5.1; Free Amino Nitrogen in Wort by Spectrophotometry (IM) Method 8.10; In: Analytica-EBC, 5th edn. Fachverlag Hans Carl, Nürenberg.

Ezeogu, L.I., Duodu, K.G., Taylor, J.R.N., 2005. Effects of endosperm texture and cooking conditions on the in vitro starch digestibility of sorghum and maize flours. J. Cereal Sci. $42,33-44$.

Figueroa, J. D.C., Martinez, B.F., Ríos, E., 1995. Effect of sorghum endosperm type on the quality of adjuncts for the brewing industry. J. Am. Soc. Brew. Chem. 53, 5-9. 
Hamaker, B.R., Kirleis, A.W., Mertz, E.T., Axtell, J.D., 1986. Effect of cooking on the protein profiles and in vitro digestibility of sorghum and maize. J. Agric. Food Chem. $34,647-649$.

International Association for Cereal Science and Technology (ICC), 2011.Standard 174.Determination of germinative energy of sorghum grain.Standard 176.Estimation of sorghum grain endosperm texture. ICC, Vienna.

Kruger, J., Oelofse, A., Taylor, J., Taylor J.R.N., 2012.Potential for improvement in yeast nutrition in raw whole grain sorghum and maize lager brewing and bioethanol production through grain genetic modification and phytase treatment. J. Inst. Brew. 118, $70-75$.

Miller, F.R., Prihoda, K.L., Rooney, L.W., Rosenow, D.T., Waniska, R.D., 1996. Registrationof a food quality sorghum restorer parent, Tx2907. Crop Science.36, 479.

Morall, R., Boyd, H.K., Taylor, J.R.N., Van der Walt, W.H., 1986. Effect of germination time, temperature and moisture on malting sorghum.J. Inst. Brew. 92, 439-445.

Mugode, L., Portillo, O.R., Hays, D.B., Rooney, L.W., Taylor, J.R.N., 2011. Influence of high protein digestibility sorghums on free amino nitrogen (FAN) production during malting and mashing. J. Inst. Brew. 227, 422-426.

Ortega Villicaña, M.T., Serna-Saldivar, S.O., 2004. Production of lagerfromsorghum malt and waxy grits. J. Am. Soc. Brew. Chem. 62, 131-139.

Osorio-Morales, S., Serna-Saldivar, S.O., Chavez-Contreras, J., Almeida-Deminguez, H.D., Rooney, W.L., 2000.Production of brewing adjuncts and sweet worts from different types of sorghum. J. Am. Soc. Brew. Chem. 58, 21-25.

Rooney, L.W., Miller, F.R., 1982. Variation in the structure and kernel characteristics of sorghum. In: Mertin, J.V. (Ed.), International Symposium on Sorghum Grain Quality. ICRISAT, Patancheru, India, pp. 143-162.

Rooney, L.W., Pflugfelder, R.L., 1986. Factors affecting starch digestibility with special emphasis on sorghum and corn. J. Anim. Sci. 63, 1607-1623. 
Sang, Y., Bean, S., Seib, P.A., Pedersen, J., Shi, Y.C., 2008.Structure and functional properties of sorghum starches differing in amylose content.J. Agric. Food Chem. 56, $6680-6685$.

Steiner, E., Auer, A., Becker, T., andGastl, M., 2012. Comparison of beer quality attributes between beers brewed with $100 \%$ barley malt and $100 \%$ barley raw material, J. Sci. Food Agric., 92, 803-813.

Taylor, J.R.N., 1992. Mashing with malted grain sorghum. J. Am. Soc. Brew. Chem. 50, 1318.

Taylor, J.R.N., Dlamini, B.C., Kruger, J., 2013. 125th Anniversary Review: The science of the tropical cereals sorghum, maize and rice in relation to lager beer brewing. J. Inst. Brew. 119, 1-14.

Taylor, J.R.N. and Emmambux, M.N., 2008. Products containing other speciality grains: sorghum, the millets and pseudocereals. In:Hamaker, B.R. (ed), Technology of Functional Cereal Products, Woodhead Publishing, Abington, UK, 2008, pp. 281-335.

Tester, R.F., Morrison, W.R., 1990.Swelling and gelatinization of cereal starches. I. Effects of amylopectin, amylose, and lipids. Cereal Chem. 67, 551-557.

Vasanthan, T., Hoover R., 2009. Barley Starch: Production, Properties, Modification and Uses.In:BeMiller, J., Whistler, R. (Ed.), Starch Chemistry and Technology. Academic Press, London, pp. 601-621.

Weaver, C.A., Hamaker, B.R., Axtell, J.D., 1998. Discovery of grain sorghum germ plasmwith high uncooked and cooked in vitro protein digestibilities. Cereal Chem. 75, $665-670$.

Wong, J.H., Lau, T., Cai, N., Singh, J., Pedersen, J.F., Vensel, W.H., Hurkman, W.J., Wilson, J.D., Lemaux, P.G., Buchanan, B.B. 2009. Digestibility of protein and starch in sorghum (Sorghum bicolor) is linked to biochemical and structural features of grain endosperm. J. Cereal Sci. 49, 73-82. 
Wu, X., Jampala, B., Robbins, A., Hays, D., Yan, S., Xu, F., Rooney, W., Peterson, G., Shi, Y.C., Wang, D., 2010. Ethanol fermentation performance of grain sorghums (Sorghum bicolor) with modified endosperm matrices.J. Agric. Food Chem. 58, 9556-9562.

Zarnkow, M., Keßler, M., Felix Burberg, Back, W., Arendt, E. K. andKreisz, S.,2007. The use of response surface methodology to optimise malting conditions of Proso Millet (PanicummiliaceumL.) as a raw material for gluten-free foods. J. Inst. Brew. 113(3), 280-292. 


\section{LEGENDS TO FIGURES}

Figure 1: Endosperm texture of the sorghum lines

NWND (non-waxy-normal protein digestibility); NWHD (Non-waxy-high protein digestibility); hWND (heterowaxy-normal protein digestibility); WND(waxy-normal protein digestibility); WHD (waxy-high protein digestibility); CE (corneous endosperm), FE (Floury Endosperm) and G (Germ),

Figure 2: TEM of protein bodies of unmalted and malted sorghum lines

NWND (non-waxy-normal protein digestibility); NWHD (Non-waxy-high protein digestibility); hWND (heterowaxy-normal protein digestibility);WND (waxy-normal protein digestibility); WHD (waxy-high protein digestibility); $\mathrm{P}=$ protein body; $\mathrm{S}=$ starch granule; $\mathrm{C}=$ cell wall); White arrow indicates irregular shaped protein bodies; Black arrow indicates normal shaped and smooth surface protein bodies; In malted lines white arrow with $\mathrm{M}$ indicates the disappearance of margins of the protein bodies; white arrow only indicates their eroded appearance.

Figure 3: SEM of proximal, mid and distal sections of sorghum lines malted for 3 days following steeping

NWND (non-waxy-normal protein digestibility); NWHD (Non-waxy-high protein digestibility); hWND (heterowaxy-normal protein digestibility); WND (waxy-normal protein digestibility); WHD (waxy-high protein digestibility); $\mathrm{PB}=$ protein body, $\mathrm{CWs}=$ smooth cell walls, $\mathrm{CWt}=$ torn cell walls; $\mathrm{SG}=$ intact starch granules, $\mathrm{SGd}=$ degraded starch granules.

Figure 4: Principal component analysis of sorghums with different starch and protein digestibility traits and their malting quality attributes: a) PCA with the exceptional line WHD1, b) PCA without WHD1

NWND (non-waxy-normal protein digestibility); NWHD (Non-waxy-high protein digestibility); hWND (heterowaxy-normal protein digestibility); WND (waxy-normal protein digestibility); WHD (waxy-high protein digestibility) 
Table 1.Endosperm texture, starch amylose content, starch and protein content, protein body size and in-vitro pepsin protein digestibility (IVPD) of the sorghum lines

\begin{tabular}{|c|c|c|c|c|c|c|}
\hline \multirow[b]{2}{*}{$\begin{array}{l}\text { Sorghum } \\
\text { line }\end{array}$} & \multirow[b]{2}{*}{ Endosperm texture } & \multirow{2}{*}{$\begin{array}{c}\text { Starch } \\
\text { amylopectin } \\
\text { content } \\
(\%, \mathrm{db})\end{array}$} & \multirow[b]{2}{*}{$\begin{array}{l}\text { Starch } \\
\text { content } \\
(\%, \mathrm{db})\end{array}$} & \multirow[b]{2}{*}{$\begin{array}{l}\text { Protein } \\
\text { content } \\
(\%, \mathrm{db})\end{array}$} & \multicolumn{2}{|c|}{ Protein digestibility traits } \\
\hline & & & & & $\begin{array}{c}\text { IVPD } \\
\text { (cooked flour) } \\
(\%, \mathbf{d b})\end{array}$ & $\begin{array}{c}\text { Protein body } \\
\text { diameter( } \mu \mathrm{m}) \\
\text { from TEM }\end{array}$ \\
\hline NWND & Corneous, Non-waxy & $79.9^{\mathrm{a}} \pm 1.1$ & $75.4^{\mathrm{a}} \pm 3.9$ & $12.2^{\mathrm{a}} \pm 0.1$ & $55.0^{\mathrm{bc}} \pm 1.8$ & $0.84 \pm 0.16$ \\
\hline NWHD & Floury, Non-waxy & $81.1^{\mathrm{ab}} \pm 1.0$ & $73.8^{\mathrm{a}} \pm 2.9$ & $13.0^{\mathrm{b}} \pm 0.2$ & $65.9^{\mathrm{d}} \pm 1.9$ & $0.81 \pm 0.24$ \\
\hline hWND & Corneous, Heterowaxy & $85.4^{\mathrm{bc}} \pm 0.1$ & $75.8^{\mathrm{a}} \pm 5.3$ & $13.0^{\mathrm{b}} \pm 0.1$ & $52.5^{\mathrm{ab}} \pm 1.6$ & $1.18 \pm 0.22$ \\
\hline WHD1 & Floury, Waxy & $87.9^{c} \pm 0.7$ & $76.1^{\mathrm{a}} \pm 4.5$ & $12.0^{\mathrm{a}} \pm 0.2$ & $62.5^{\mathrm{d}} \pm 1.9$ & $* 0.48 \pm 0.10$ \\
\hline WND1 & Intermediate, Waxy & $88.7^{\mathrm{cd}} \pm 0.9$ & $73.8^{\mathrm{a}} \pm 2.9$ & $13.8^{\mathrm{c}} \pm 0.1$ & $48.9^{\mathrm{a}} \pm 1.9$ & $0.89 \pm 0.17$ \\
\hline WND2 & Corneous, Waxy & $89.1^{\text {cde }} \pm 2.5$ & $73.0^{\mathrm{a}} \pm 4.7$ & $13.4^{\mathrm{bc}} \pm 0.2$ & $56.4^{\mathrm{bc}} \pm 1.7$ & $1.25 \pm 0.16$ \\
\hline WHD2 & Floury, Waxy & $93.6^{\mathrm{de}} \pm 2.0$ & $74.7^{\mathrm{a}} \pm 1.5$ & $13.4^{\mathrm{bc}} \pm 0.2$ & $57.1^{\mathrm{c}} \pm 1.7$ & $* 0.56 \pm 0.06$ \\
\hline WND3 & Intermediate, Waxy & $94.1^{\mathrm{e}} \pm 0.4$ & $78.5^{\mathrm{a}} \pm 4.6$ & $13.0^{\mathrm{b}} \pm 0.2$ & $49.1^{\mathrm{a}} \pm 1.8$ & $1.45 \pm 0.22$ \\
\hline
\end{tabular}

Values are Mean \pm standard deviation $(n=2)$. Values in a column with different letter superscripts are significantly different $(\mathrm{p}<0.05)$. NWND (Non-waxy-normal protein digestibility); NWHD (Non-waxy-high protein digestibility); hWND (heterowaxy-normal protein digestibility);WHD (waxy-high protein digestibility);WND (waxy-normal protein digestibility); *lines had irregular shaped protein bodies. 
Table 2.Malt and malting quality attributes of malt prepared from waxy and high protein digestibility sorghum lines and commercial barley malt references

\begin{tabular}{|c|c|c|c|c|c|c|c|}
\hline \multirow{2}{*}{$\begin{array}{l}\text { Sorghum } \\
\text { line }\end{array}$} & \multicolumn{4}{|c|}{ Malt Quality } & \multicolumn{3}{|c|}{ Malting Quality } \\
\hline & $\begin{array}{c}\text { a-amylase } \\
\text { (CU/g db) }\end{array}$ & $\begin{array}{l}\beta \text {-amylase } \\
\text { (BU/g db) }\end{array}$ & $\begin{array}{c}\text { HWE } \\
{\left[{ }^{\mathbf{0}} \mathbf{P}\right](\%, \mathbf{d b})}\end{array}$ & $\begin{array}{c}\text { FAN } \\
(\mathrm{mg} / 100 \mathrm{~g} \mathrm{db})\end{array}$ & $\begin{array}{l}\text { Malting } \\
\text { loss }(\%)\end{array}$ & $\begin{array}{c}\text { Starch loss } \\
(\%)\end{array}$ & $\begin{array}{c}\text { Protein loss } \\
(\%)\end{array}$ \\
\hline NWND & $113.2^{\mathrm{e}} \pm 1.0$ & $4.0^{\mathrm{de}} \pm 0.4$ & $51.1^{b c} \pm 0.3$ & $76.3^{\mathrm{bc}} \pm 1.2$ & $11.0^{\mathrm{a}} \pm 1.8$ & $8.4^{\mathrm{a}} \pm 1.0$ & $2.61^{\mathrm{a}} \pm 0.26$ \\
\hline NWHD & $102.3^{\mathrm{e}} \pm 1.2$ & $4.0^{\mathrm{ef}} \pm 0.3$ & $50.5^{b c} \pm 0.7$ & $99.6^{\mathrm{e}} \pm 3.6$ & $11.2^{\mathrm{a}} \pm 0.3$ & $10.5^{\mathrm{abc}} \pm 1.6$ & $4.98^{\mathrm{c}} \pm 0.40$ \\
\hline hWND & $106.3^{\mathrm{d}} \pm 1.7$ & $2.1^{b} \pm 0.3$ & $55.2^{\mathrm{cd}} \pm 1.8$ & $82.2^{\mathrm{cd}} \pm 2.1$ & $14.1^{\mathrm{a}} \pm 1.3$ & $10.4^{\mathrm{ab}} \pm 1.6$ & $4.84^{\mathrm{c}} \pm 0.62$ \\
\hline WHD1 & $79.3^{\mathrm{b}} \pm 0.8$ & $2.3^{b c} \pm 0.3$ & $44.2^{\mathrm{b}} \pm 0.9$ & $71.5^{\mathrm{b}} \pm 1.5$ & $12.0^{\mathrm{a}} \pm 0.1$ & $10.8^{\mathrm{abc}} \pm 1.4$ & $3.50^{\mathrm{ab}} \pm 0.28$ \\
\hline WND1 & $99.2^{\mathrm{c}} \pm 1.8$ & $3.4^{\mathrm{cd}} \pm 0.1$ & $59.7^{\mathrm{de}} \pm 2.1$ & $103.2^{\mathrm{e}} \pm 4.6$ & $16.0^{\mathrm{a}} \pm 0.5$ & $13.5^{\mathrm{cd}} \pm 0.8$ & $3.54^{\mathrm{ab}} \pm 0.34$ \\
\hline WND2 & $126.0^{\mathrm{f}} \pm 1.7$ & $3.6^{\mathrm{d}} \pm 0.2$ & $58.6^{\mathrm{de}} \pm 3.3$ & $83.8^{\mathrm{d}} \pm 4.8$ & $14.3^{\mathrm{a}} \pm 1.6$ & $11.6^{\mathrm{bcd}} \pm 1.5$ & $3.62^{\mathrm{b}} \pm 0.49$ \\
\hline WHD2 & $168.5^{\mathrm{h}} \pm 0.8$ & $4.2^{\mathrm{de}} \pm 0.1$ & $64.2^{\mathrm{ef}} \pm 1.0$ & $80.6^{\mathrm{cd}} \pm 4.6$ & $13.1^{\mathrm{a}} \pm 0.8$ & $14.1^{\mathrm{d}} \pm 1.6$ & $4.85^{\mathrm{c}} \pm 0.55$ \\
\hline WND3 & $136.3^{\mathrm{g}} \pm 0.2$ & $4.8^{\mathrm{e}} \pm 0.1$ & $62.0^{\mathrm{de}} \pm 0.7$ & $85.0^{\mathrm{d}} \pm 3.3$ & $14.3^{\mathrm{a}} \pm 2.1$ & $14.7^{\mathrm{d}} \pm 0.5$ & $7.21^{\mathrm{d}} \pm 0.32$ \\
\hline SMC & $26.0^{\mathrm{a}} \pm 1.5$ & $0.6^{\mathrm{a}} \pm 0.1$ & $36.2^{\mathrm{a}} \pm 0.6$ & $26.2^{\mathrm{a}} \pm 1.6$ & \multirow{2}{*}{\multicolumn{3}{|c|}{ Not applicable }} \\
\hline $\mathrm{BMC}$ & $131.2^{\mathrm{fg}} \pm 0.9$ & $12.0^{\mathrm{f}} \pm 0.4$ & $70.4^{\mathrm{f}} \pm 1.5$ & $83.5^{\mathrm{d}} \pm 3.3$ & & & \\
\hline $\begin{array}{l}\text { Desired } \\
\text { barley } \\
\text { malt } \\
\text { quality } \\
\text { for } \\
\text { brewing }\end{array}$ & $200-250^{*}$ & $500^{*}$ & $>81.0^{* *}$ & $130-160^{* *}$ & & & \\
\hline
\end{tabular}

Values are Mean \pm standard deviation $(\mathrm{n}=2)$.Values in a column with different letters in superscript are significantly different (p<0.05). CU (Ceralpha Unit), BU (Betamyl-3® Unit; db (dry basis); NWND (Non-waxy-normal protein digestibility); NWHD (Non-waxy - high protein digestibility), hWND (heterowaxy- normal protein digestibility), WHD (waxy-high protein digestibility), WND (waxy-normal protein digestibility), SMC = commercial sorghum malt), BMC = commercial barley malt.* (Zarnkow et al., 2007), **(Steiner et al., 2012). 


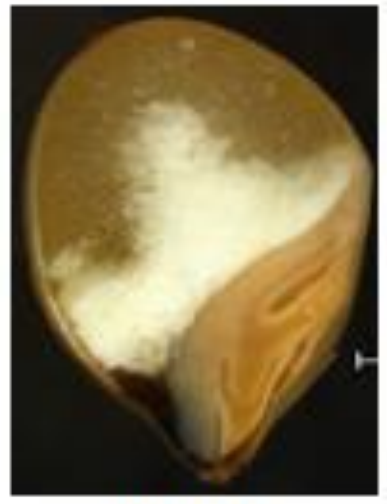

NWND

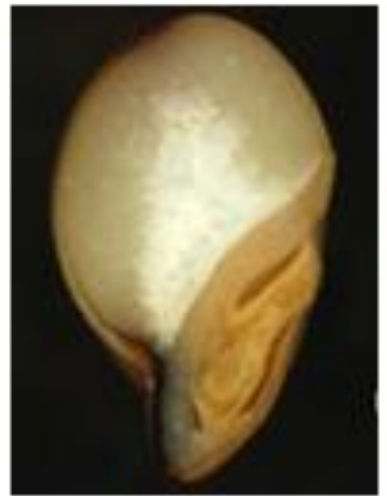

WND1

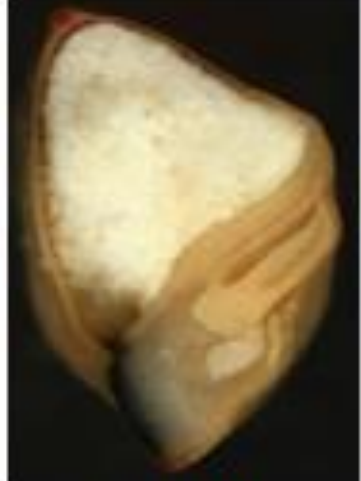

NWHD

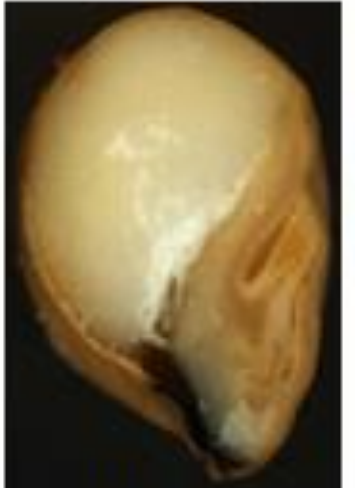

WND2

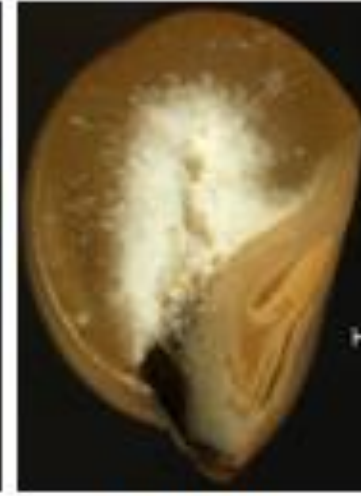

hWND

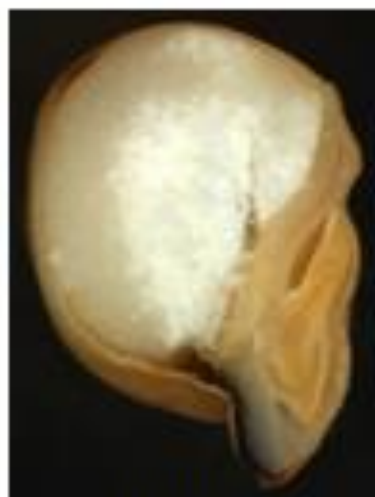

WHD2

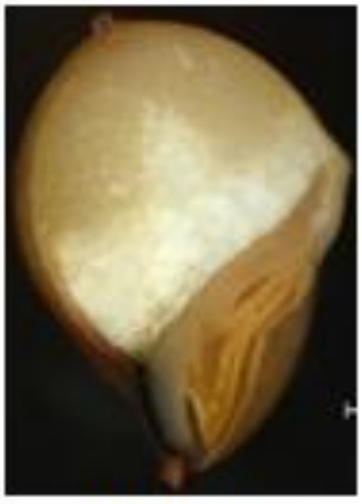

WHD1

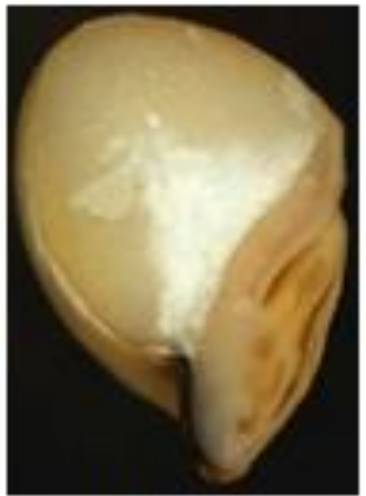

WND3

Figure 1: Endosperm texture of waxy and high protein digestibility sorghum lines. NWND (non-waxy, normal protein digestibility), NWHD (non-waxy high protein digestibility), hWND (heterowaxy-normal protein digestibility), WND1, WND2 and WND3 (waxy-normal protein digestibility); WHD1 and WHD2 (waxy-high protein digestibility)

FIGURE 1 


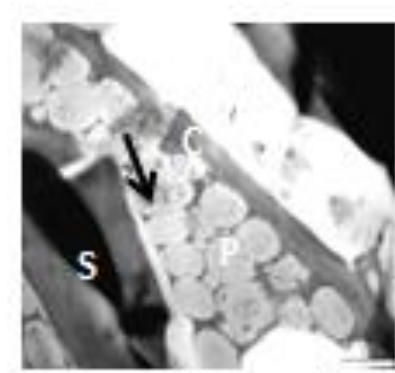

NWND (raw grain)

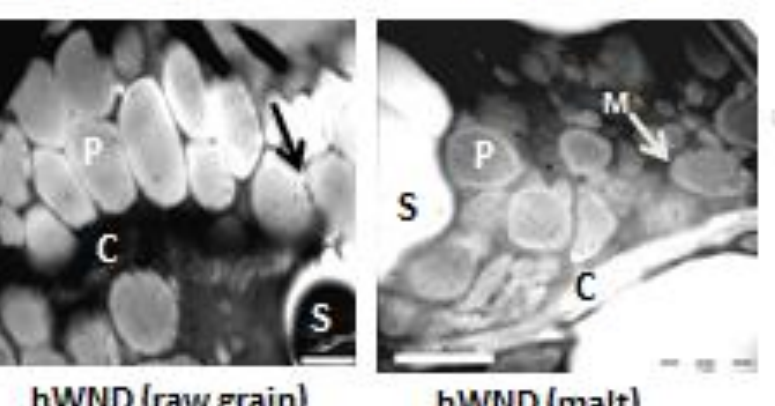

hWND (raw grain)

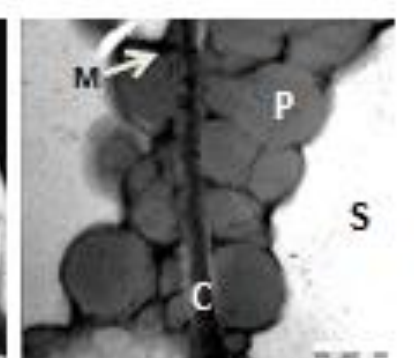

NWND (malt)

hWND (malt)

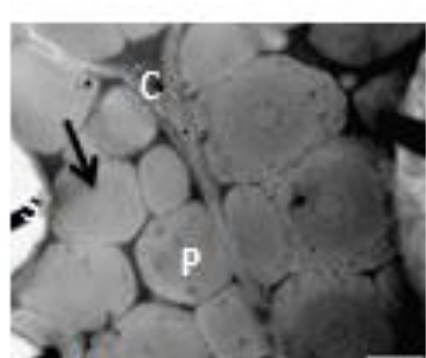

NWHD (raw grain)

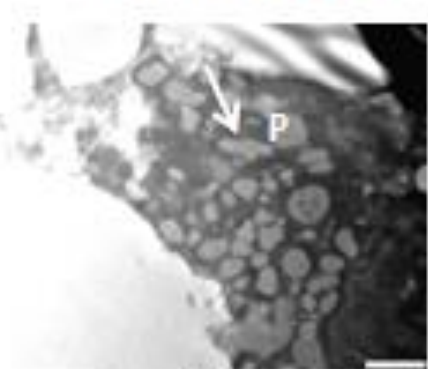

WHD1 (raw grain)

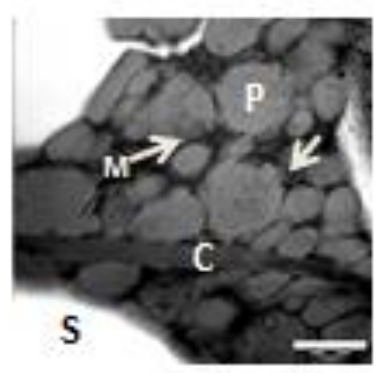

NWHD (malt)

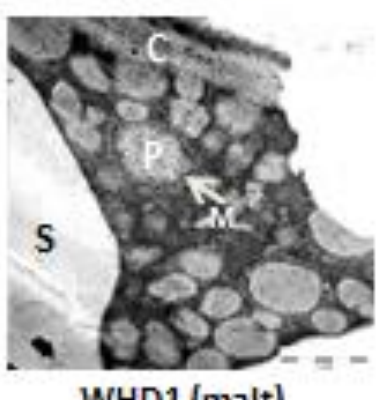




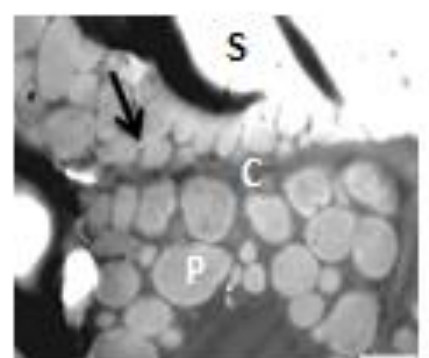

WND1 (raw grain)

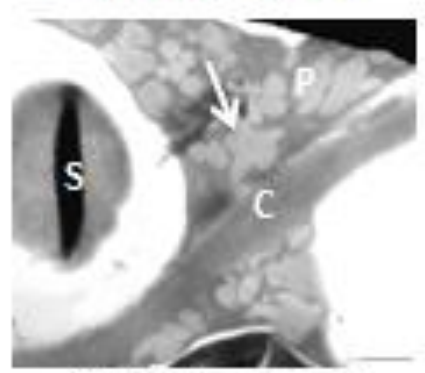

WHD2 (raw grain)

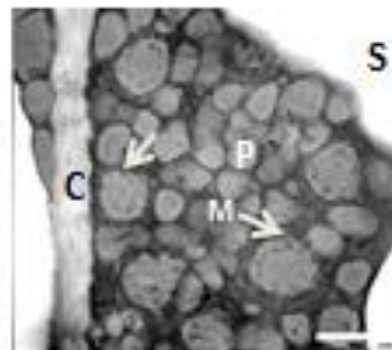

WND1 (malt)

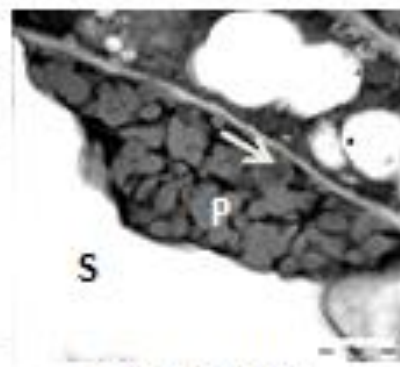

WHD2 (malt)

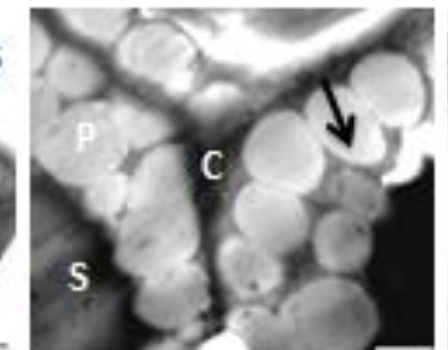

WND2 (raw grain]

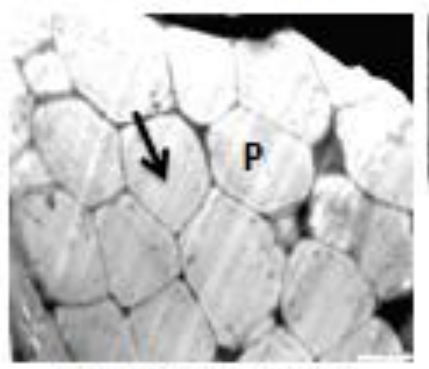

WND3 (raw grain]

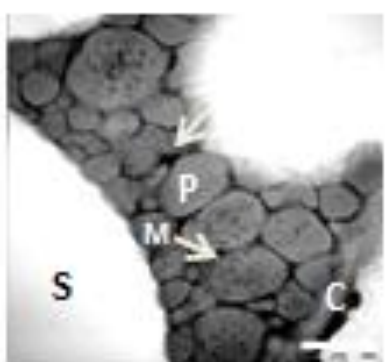

WND2 (malt)

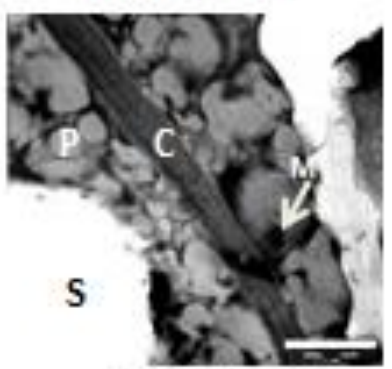

WND3 (malt)

Figure 2. TEM of protein bodies in endosperm of unmalted and malted sorghum lines: $P=$ protein body; $S=$ starch granule, $\mathrm{C}=$ cell wall; White arrow in raw grain indicates irregular shaped protein body and black arrow indicates normal shaped and smooth surface protein body. While in malted grain an white arrow with M indicates the disappearance of margins of the protein bodies and white arrow only indicates the eroded appearance NWND (Non-waxy-normal protein digestibility), NWHD (Non-wary-high protein digestibility), hWND (heterowaxy - normal protein digestibility), WHD (Waxy-High protein digestibility) and WND (Waxynormal protein digestibility), Bar is 1 um. 


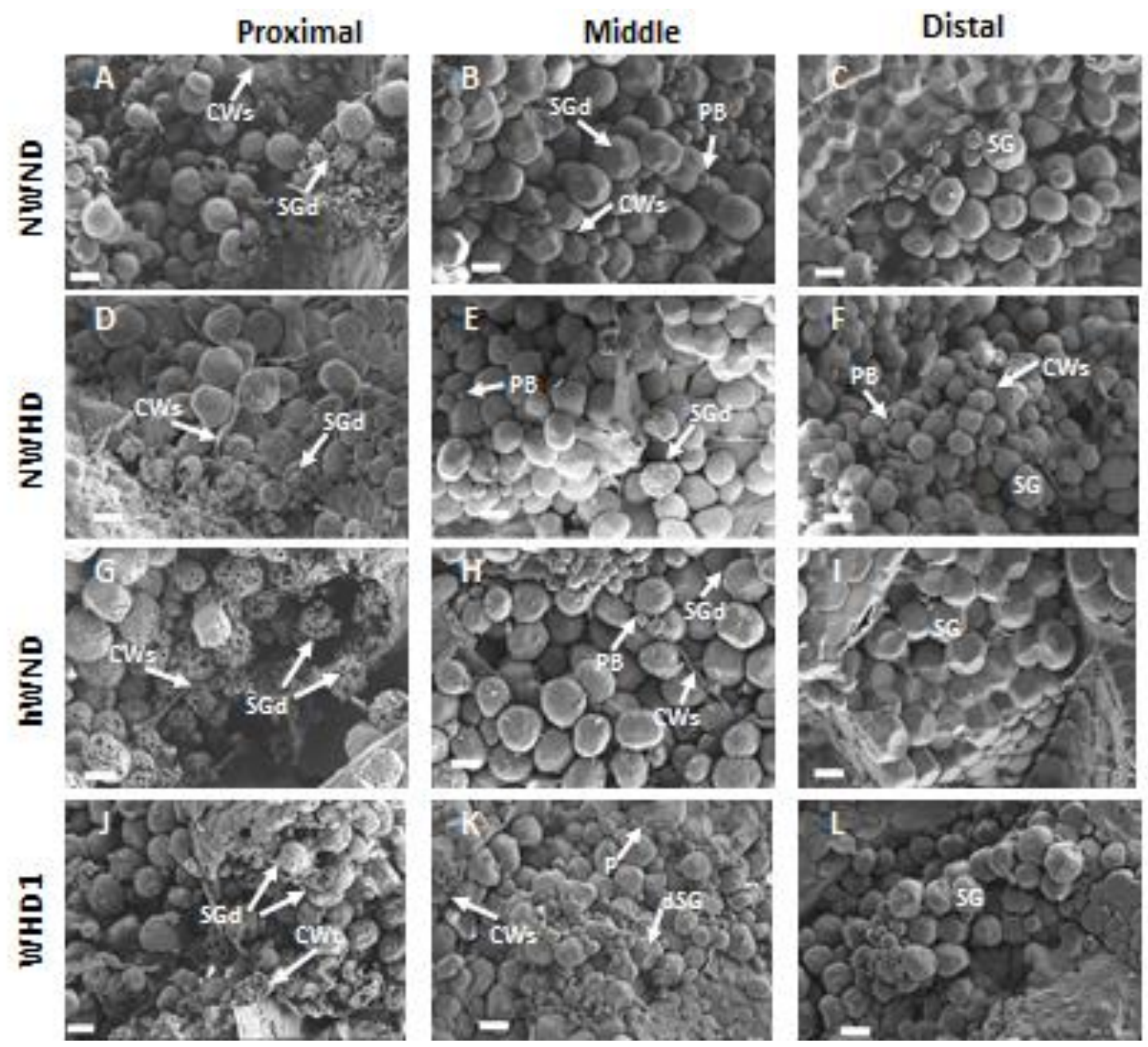




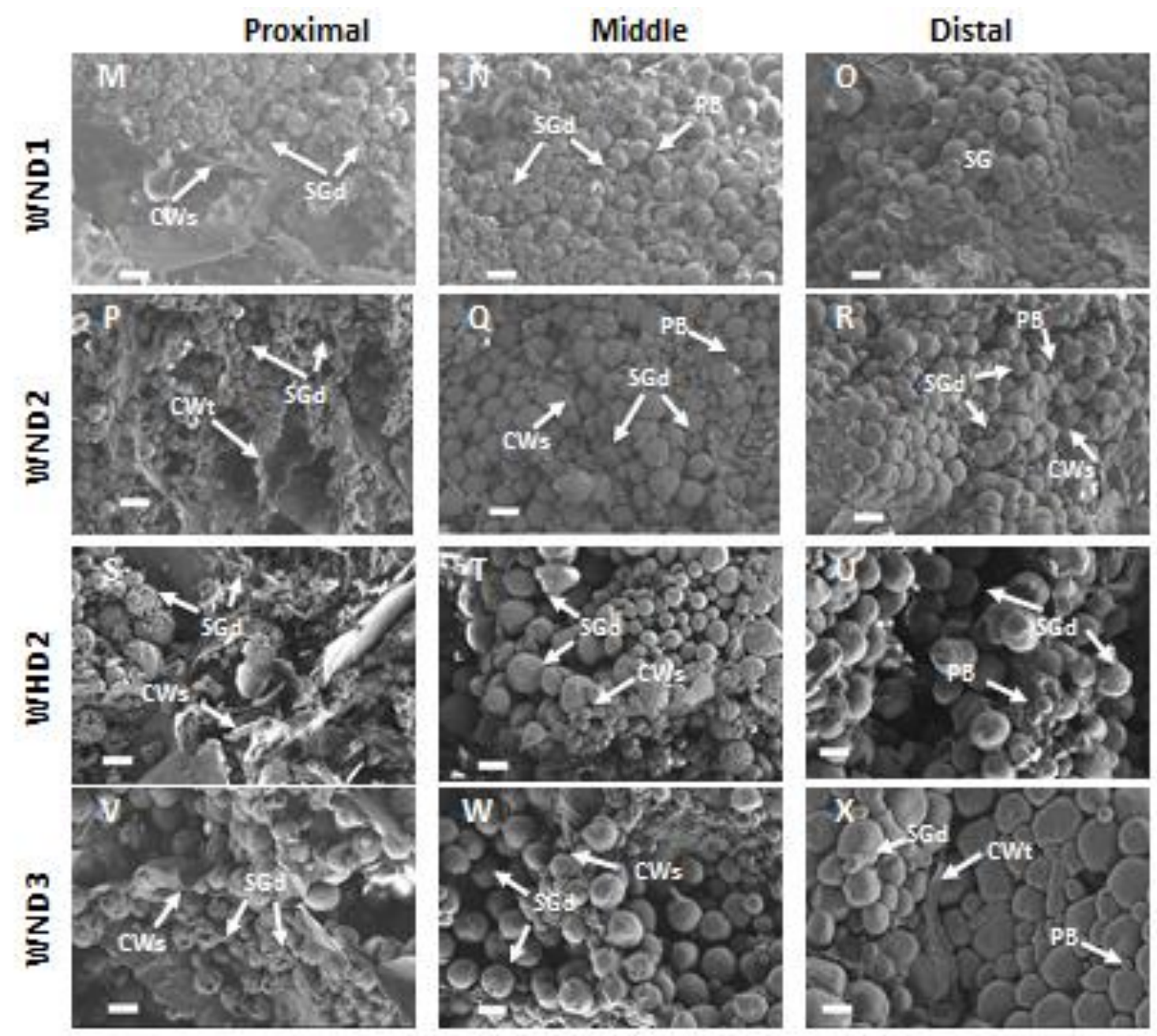


Figure 3. SEM of proximal, mid and distal sections of sorghum lines with different starch type and protein digestibility malted for 3 days following steeping. NWND (Non-waxy, normal protein digestibility), NWHD (Non-waxy, high protein digestibility), hWND

(Heterowaxy-normal protein digestibility), WHD (Waxy-High protein digestibility), WND

(Waxy-normal protein digestibility); $\mathrm{CWs}=$ smooth cell walls; $\mathrm{CWt}=$ torn cell walls; $\mathrm{SG}=$ intact starch granules; SGd = degraded starch granules; and PB = protein bodies. Bar is 10 $\mu \mathrm{m}$. 
A

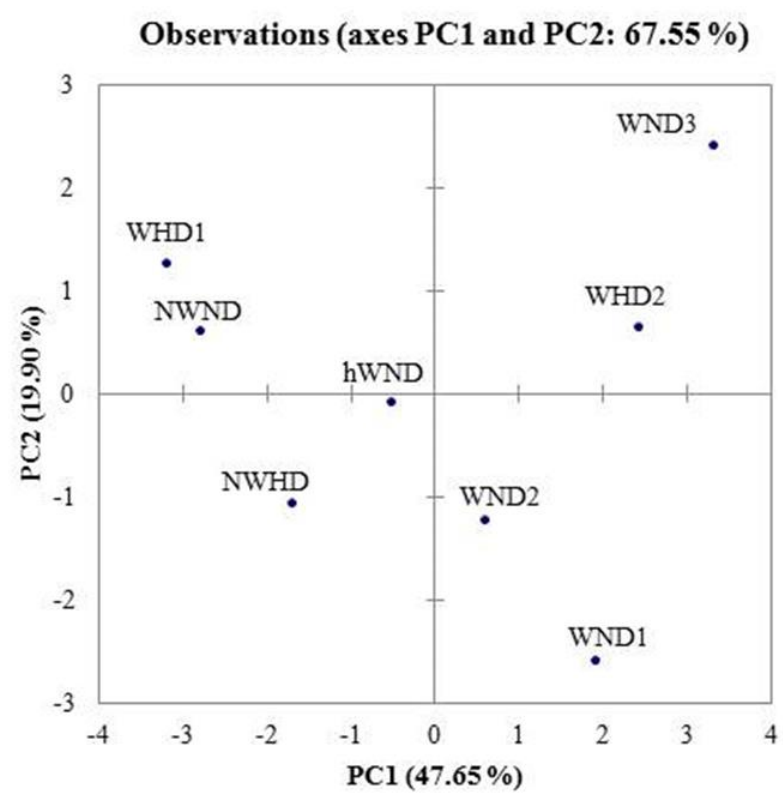

B

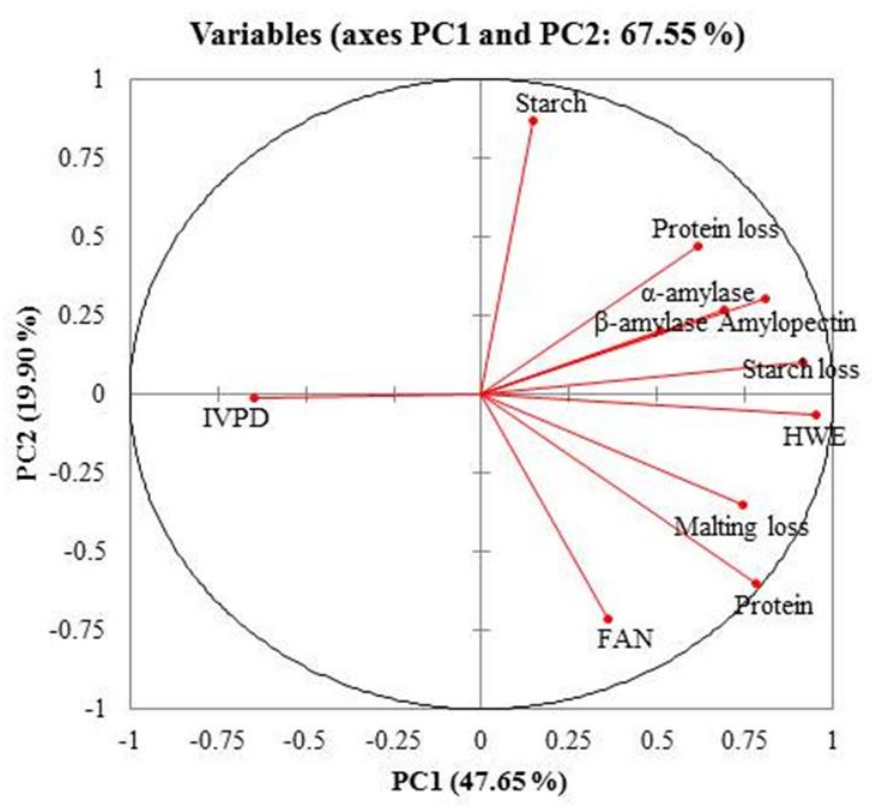

Figure 4a 
A

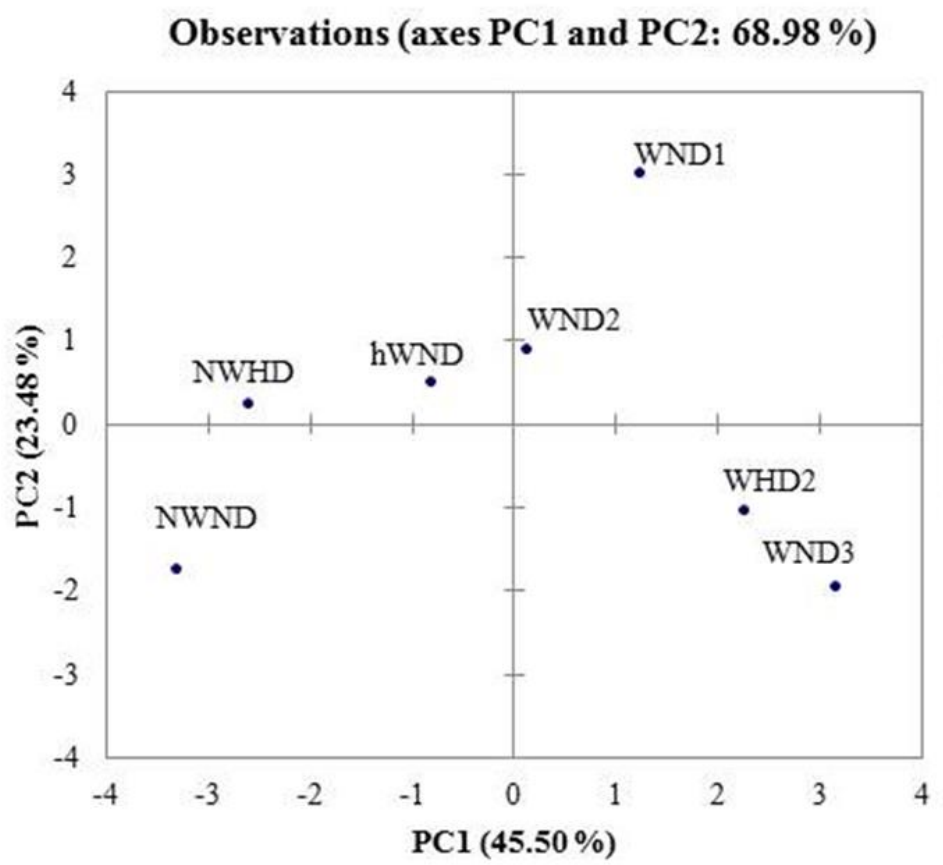

B

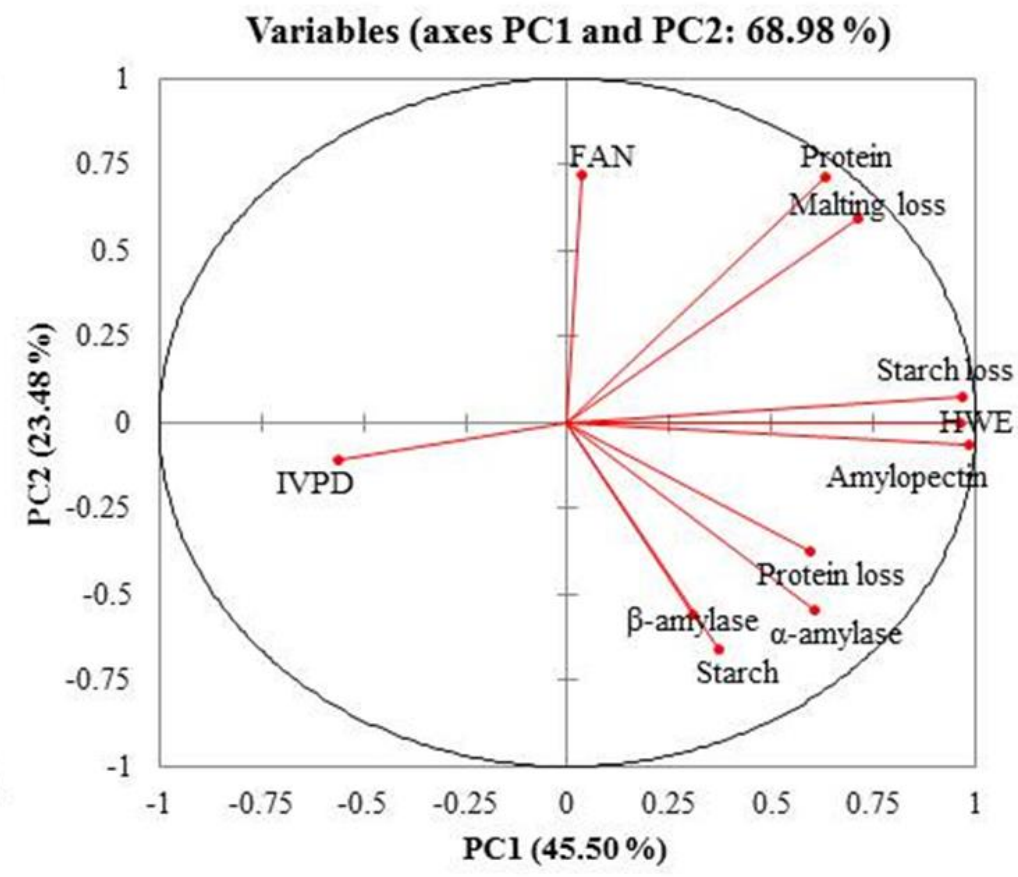

Figure 4b 